Chapter 3

\title{
Images of the Ireneu Segarra Method and its Uses in Schools at the Onset of Music Education Redevelopment in Catalonia
}

\section{Introduction}

The collection of photographs considered here comes from the School of Musical Pedagogy-Ireneu Segarra Method (SMP-ISM) and contains images taken between 1974 and 2003. The images are organized into three amateur photo albums that are all housed in the Music Archives at the Abbey of Montserrat, in a special section that stores all the SMP-ISM's archival collections.

The main objective of the current chapter ${ }^{1}$ is to analyze a specific selection of photographs that were taken during a 1984 music class at the Autonomous University of Barcelona's (UAB by its Catalan initials) Student Teaching School. All five of the images shown below were taken by a professional photographer to be published in a book commemorating the ten-year anniversary of the SMP-ISM. ${ }^{2}$

The relevance of this particular collection of photographs is that they are an iconographic compilation of the innovations that the Ireneu Segarra method contributed to primary education. To contextualize the collection, we first provide an overview of the movement to redevelop music teaching at the SMP-ISM in Catalonia, at a time defined by the rollout of Spain's General Education Law. We also give a brief account of the SMP-ISM's photographic archives and the publication for which these particular photos were taken. Finally, we conduct an in-depth analysis of our set of images based on their intrinsic value as historical evidence and relevance in painting a picture of the iconography surrounding the redevelopment of music teaching in schools, their intended visibility, and use as propaganda. This analysis arises from the belief that photography not only witnesses historic events, but also serves to shape an explanatory and justificatory discourse of reality. The specific analysis of the photographs was performed at three levels - analysis of the image itself, historical context, and interpretation - and mainly inspired by the iconographic method of

1 This chapter was written as part of the project School Culture and Practices in the 20th Century, funded by ERDF/ Ministerio de Ciencia, Innovación y Universidades-Agencia Estatal de Investigación/ EDU2017- 82485-P All original Catalan and Spanish names of institutions, places or organizations can be found in cited works in the footnotes and in the bibliography of the current chapter. 2 Escola de Pedagogia Musical-Mètode Ireneu Segarra, Opuscle commemoratiu dels 10 anys de l'Escola de Pedagogia Musical (Barcelona: Patronat Pro-Música, Fundació Güell, 1984). 
art historian Erwin Panofsky. ${ }^{3}$ This methodological approach guided our reading of these photographs and provided a contrast against other non-visual secondary sources under analysis. Likewise, we looked at photographs using Benjamin's historical deconstruction approach: images have the power to let us discover countless histories (of the unconscious), they provide perspectives that can be timeless, and were often made by artist-historians to demystify existing narratives, establish political opposition, and undertake a critical discourse of the past. ${ }^{4}$

\section{The School of Musical Pedagogy, the Ireneu Segarra Method, and the Redevelopment of Music Teaching in Catalonia}

As of today, various studies and works have been published on the SMP-ISM and what the institution stood for at its beginnings and throughout its existence. Regarding the school and its efforts to spread Ireneu Segarra's music teaching method, published works include commemorative writings, ${ }^{5}$ publications drafted by some of the main actors involved in the development of the school, ${ }^{6}$ studies on the school's methodological influence in redeveloping music teaching beyond the borders of Catalonia, ${ }^{7}$ and studies on the beginnings of the SMP-ISM and the movement to redevelop music teaching in Catalonia during the 1970s that relay oral testimony ${ }^{8}$ and focus on linking music teaching with Catalan language and culture. ${ }^{9}$

3 Erwin Panofsky, Studies in Iconology: Humanistic Themes in the Art of the Renaissance (1939) (Boulder CO, USA: Taylor and Francis, 1972).

4 Miguel A. Hernández-Navarro, Materializar el pasado: el artista como historiador (benjaminiano) (Murcia: Micromegas, 2012), 43-66; Walter Benjamin, Discursos interrumpidos I (Buenos Aires: Taurus, 1989).

5 Escola, Opuscle commemoratiu.

6 Joaquim Garrigosa, "L'Escola de Pedagogia Musical-Mètode Ireneu Segarra," Perspectiva escolar 155 (1991): 16-19; Joaquim Miranda, "El mètode Ireneu Segarra i l'escola de pedagogía musical," in Primer Congrés de Música de Catalunya, AA. VV. (Barcelona: Consell Català de la Música, 1994), 299-303; Joan Cortina, "L'Escola de Pedagogia Musical-Mètode Ireneu Segarra," in Ireneu Segarra. Mig segle de mestratge musical, AA. VV. (Barcelona: Abadia de Montserrat, 1998), 57-59.

7 Llorenç Gelabert, “Aproximación histórica y metodológica a los cursos de pedagogía musical de la Universitat de les Illes Balears (1977-1990)," Historia de la Educación. Revista Interuniversitaria 34 (2015): 337-356.

8 Llorenç Gelabert and Xavier Motilla, "Aproximación al movimiento de renovación de la práctica educativa a través de la Escuela de Pedagogía Musical-Método Ireneu Segarra,” in La Práctica Educativa. Historia, Memoria y Patrimonio, ed. Sara González et al. (Salamanca: FahrenHouse, 2018), 573-582.

9 Llorenç Gelabert and Xavier Motilla. "Renovación de la enseñanza de la música e identidad catalana en los inicios de la Escuela de Pedagogía Musical-Método Ireneu Segarra," in 20 Coloquio 
The SMP-ISM was founded in 1973, mainly to spread the pedagogy developed by Ireneu Segarra in the early 1970s in Catalonia. It intended to contribute to standardizing music teaching and began by researching, creating, and experimenting with a teaching program that could be applied at all phases of mandatory education, and at music schools and conservatories. The goal was to provide a new vision of the teaching and learning processes associated with music. The school carried out training courses for teachers and professors in order to complement their original training. It published textbooks and teaching materials specifically related to the Ireneu Segarra method, so that they could be used in other general basic education courses under the framework laid out in Spain's General Education Law. The SMP-ISM also published other books and materials on musical language that were designed to be used in music schools and conservatories. ${ }^{10}$

As developed by Ireneu Segarra, the method emphasized adapting musical education to the age of the child. The method included working on the following musical parameters: a) Intonation, b) singing (based on folk songs), c) rhythm/movement/ dance, and finally d) listening. During its initial stages of implementation, the method focuses on learning the basic notions such as the relationships between sounds, knowledge of musical literature, and a detailed study of Catalan folk songs. With this method, children were progressively introduced to the range of subjects that could be studied at higher levels: reading, analysis, transposition, harmony, accompaniment, improvisation, choral and orchestral ensembles, conducting, composition, etc. ${ }^{11}$ The method was structured around a variety of materials divided into eight separate levels. Ireneu Segarra dedicated 20 years to this specific part of the method. She wrote instruction books for each of the levels, aimed at teachers, Iniciacio a la Música (Introduction to Music), and at students, El meu llibre de música (My music book), as well as four activity books (focusing on visual elements) and two songbooks, Juguem cantant (We play singing). ${ }^{12}$

Historia de la Educación. Identidades, Internacionalismo, Pacifismo y Educación (s. 19 y 20), ed. Xosé M. Cid et al. (Ourense: SEDHE, Deputación de Ourense, 2019), 261-266.

10 Cortina, "L’Escola de Pedagogia Musical-Mètode Ireneu Segarra," 57-59; Garrigosa, "L’Escola de Pedagogia Musical-Mètode Ireneu Segarra," 16-19; Gelabert and Motilla, "Aproximación al movimiento de renovación de la práctica educativa," 573-582.

11 Riera, "L’aportació pedagògica," 37-55.

12 Textbooks and teaching materials detailing the Ireneu Segarra method are referenced in this chapter's final bibliography. They were the objects of analysis in Llorenç Gelabert and Xavier Motilla, "School Textbooks, Didactic Material and a New Approach in Music Teaching in Catalonia with the Opening of the School of Musical Pedagogy-Ireneu Segarra Method," History of Education \& Children's Literature 15, no. 2 (2020): 183-198. 
Various studies ${ }^{13}$ have highlighted the important contributions of the SMP-ISM, and use of the Ireneu Segarra method, to the process of redeveloping and standardizing music teaching in Catalonia and other Catalan speaking regions. This process coincided with the general redevelopment of Spanish teaching methodologies that took place during the final years of Francoism and the transition to democracy. The political context of those years marked the beginning of a new stage of pedagogical renewal in Catalonia, which had been interrupted by the Spanish Civil War. The SMPISM, along with other institutions and updated teaching initiatives across Catalonia, actively contributed to these changes. Noteworthy is the link between the SMP-ISM and the active teaching legacy - stemming from the New School and Progressive Education movements - that was incorporated into music education using Zoltán Kodály's (1882-1967) original, internationally accepted methodology, and which was adapted and translated to a Catalan context by Ireneu Segarra. In addition to Ireneu Segarra, we found many references that testify to the implementation of active teaching. In most cases, these references refer to teachers, pedagogues and/or musicians. Good examples are the contribution of Joan Llongueras to adapting and introducing the Dalcroze method in Catalonia, ${ }^{14}$ and the significant influence in Spain of Francisco Giner de los Ríos, Manuel Borgunyó and Luis Elizalde. ${ }^{15}$

\section{The SMP-ISM's Photographic Archives}

The collection of photos from the SMP-ISM, located in the Music Archives at the Abbey of Montserrat, consists of three amateur photo albums containing a total of 570 photographs of various types. The first album, with a total of 159 photos, covers the period 1974-1985. The second has 170 photos, all from 1988. While the third album includes 241 photos taken between 1988 and 2003.

13 Gelabert, “Aproximación histórica y metodológica a los cursos de pedagogía musical,” 337-356; Gelabert and Motilla, "Renovación de la enseñanza de la música e identidad catalana," 261-266; Gelabert and Motilla, "Aproximación al movimiento de renovación de la práctica educativa," 573-582.

14 Francisca Comas, Bernat Sureda and Xavier Motilla, "Pedagogical innovation and music education in Spain: Introducing the Dalcroze method in Catalonia," Paedagogica Historica 50, no. 3 (2014): 320-337.

15 Ferran Riesgo, "Reformismo, difusión y legado musical de Francisco Giner de los Ríos," Anales de literatura española 27 (2015): 107-129; José Luis Heredia Agóiz, "Manuel Borguño y el método eurítmico vocal y tonal,” Música y educación: Revista trimestral de pedagogía musical 100 (2014): 44-65; Javier González Martín, Manuel Borguñó y la educación musical en España. Historia y avatares de una frustración (Almeria: Universidad de Almería, 2016), doctoral thesis, directed by Juan Fernández Sierra; Luis Elizalde, Canto escolar: material pedagógico para la formación musical en la EGB basado en el folklore español (Madrid: Publicaciones Claretianas, Escuela Superior de Pedagogía Musical, 1990). 
We first produced an inventory and cataloged the photos of the SMP-ISM for analysis. To do this, we considered a variety of recent suggestions for classifying schooland education-related photographs. ${ }^{16}$ However, the specific nature of the institution and photos being analyzed made it necessary for us to consider several typologies, categories, descriptions, etc., for cataloging the school photos. These provided us with a clearer and more accurate conception of the ideas behind the collection and the photos themselves. About what does this imply, it is worth noting that the wide range of typologies sometimes makes it difficult to classify the photos. For this reason, we consulted many of the personal testimonies that appear along with the photographs and interviewed some of those who appear in them. Thus, we were able to find out specifically what kinds of activities were taking place based on individuals' recollections.

The first photo album contains images of the first SMP-ISM courses for music teachers (carried out in Parets del Vallès in 1974 and 1975, in Sentmenat in 1976, in Vilanova in 1979, in the Collell Monastery in 1980, in the Abbey of Montserrat and Santa Cecilia in 1981 and 1982, in La Llobeta in 1983, and in Berga in 1985). The photos show the beginnings and consolidation of the institution. Noteworthy in this first album is the number of photos (100 of 159) that capture the classroom activities of various courses: theory classes, practical classes with instruments, choir singing classes, drama/staging classes, movement/dance classes, phonomimy (using gestures to represent sounds), etc. The most commonly depicted moments are linked to the innovative aspects of the method used for teaching music, such as the use of drama/staging, rhythm/movement/dance, and choral singing. There are also many photos related to listening, which reflects an aspect closer to the traditional concept of music teaching. In addition, there are group photos as well as images capturing a variety of other aspects (teachers scheduling courses, eating, free time, closing ceremonies for courses, etc.).

The second album contains photos exclusively from 1988 that capture celebrations of the $15^{\text {th }}$ anniversary of the SMP-ISM (170 photos in total). The third and final album largely corresponds to the 1988-2003 period, and contains photos of the institution's twentieth and twenty-fifth anniversaries (130 and 46 photos, respectively). However, there are other, more interesting photos in this album. One set of twenty images captures various SMP-ISM courses during the period. Another set includes 22 photos from 1984 (mistakenly included in the third album) that show a music class with children at the UAB's Student Teaching School, where the Ireneu Segarra method was used. It is these photos that are the subject of our present analysis. This specific collection of black and white photos was taken by a professional photographer and was

16 Francisca Comas et al., "Escuela y fotografía, entre el testimonio y la construcción del discurso narrativo," in Patrimonio y Etnografía de la escuela en España y Portugal durante el siglo XX, ed. Pedro L. Moreno et al. (Murcia: SEPHE, CEME, Universidad de Murcia, 2012), 405-417. 
destined to be included in a publication commemorating the tenth anniversary of the SMP-ISM. In the end, seven of the 22 photos were used, either partially or in their entirety, in this commemorative publication. ${ }^{17}$

\section{The Publication Commemorating the Tenth Anniversary of the SMP-ISM}

The school wanted to publicize itself and show its work to the world in a commemorative, illustrated booklet for its tenth anniversary. The publication contains written texts and contributions from various known and unknown authors. It includes different sections covering the significance of the method from its creator's point of view. ${ }^{18}$ Further, it offers information on the creation of the school, the main characteristics and aspects of the music teaching method created by Ireneu Segarra, the courses offered by the SMP-ISM, and aspects related to the real-life application of the teaching method in early childhood education, primary education, and in music schools and conservatories. The booklet also includes a timeline of the activities that were carried out, course attendance statistics by year, a biographical note on the creator of the ideology behind the method, a map showing where SMP-ISM course attendees came from, opinions on the work being done at the school from various figures in the worlds of teaching and music in Catalonia, a bibliography of the teaching materials and publications employed by the method, and finally, information on the teaching staff, managers and administrators of the SMP-ISM at the time the publication was created. ${ }^{19}$ In total, 16 photographs were included in the booklet, of which seven belong to the collection of photos taken specifically for the commemorative publication. The other photos are of the first year of the SMP-ISM (three), the creator of the method (three), and teachers or students (three).

The publication aimed to depict the work done by the institution over ten years of vigorous teaching activities, which included intensive summer courses, debates and work meetings throughout the school year, the creation of materials, etc. In the commemorative booklet, explanations are combined with a number of iconic and illustrative images showing the most representative elements of Segarra's and the SMP-ISM's legacy. The photos complement and underscore the texts via carefully selected photos reflecting the innovative education that the institution aimed to

17 Escola, Opuscle commemoratiu, 4, 7, 11, 14, 17-19, 21, 22, 25, 29, 31, 33, 38.

18 Ireneu Segarra, "Per què el mètode," in Escola, Opuscle commemoratiu, 5.

19 Escola, Opuscle commemoratiu, 6-40. Short texts were written by Marta Mata Garriga, Oriol Martorell, Jordi Galí, Josep M. Ainaud de Lasarte, M. Antònia Canals, Josep M. Mestres Quadreny, Carles Guinovart, Carme Àngel, Josep Crivillé Bargalló, and Cassià M. Just. 
impart. The seven selected photographs show classroom situations that demonstrate some of the learning strategies and tools used by the Ireneu Segarra method at the SMP-ISM.

\section{Description and Analysis of the Collection of SMP-ISM Photographs on Music Teaching in Primary Schools}

In his studies on domestic photography, Pierre Bourdieu ${ }^{20}$ provides guidelines for analyzing the priority objective of photography in the field of education. This priority objective is mainly focused on preserving the historical memory of the photographed element or institution through the initiatives and activities being performed. Some of these initiatives end up becoming iconographic elements of the institution and, thus, are worthy of being photographed. Photography itself includes pre-existing elements that provide us with objective information on furniture, facilities, instruments, books, and individuals that have leading roles at specific moments and in specific situations, whether individually or collectively. The approach to photography should also be considered, since the photographer or the entity or institution requesting the photographs serve as ingredients that condition the final results. According to Barthes, ${ }^{21}$ photography presents the ability to transform or even lie about meaning. Not everything is photographed: instead, only those things that are considered worthy of standing the test of time are given consideration.

Such insights into the purposes of photography are true for the collection of 22 photos that are the subject of our analysis. The images appear to naturally reflect the spontaneous actions of the subjects being photographed during a session in a music classroom, but were instead taken during a photo session requested by the SMP-ISM to be used as propaganda and advertising for the Ireneu Segarra method. Thus, they show an induced teaching situation that deliberately focused on innovative teaching practices that the institution wished to showcase as a good representation of itself.

Beyond the posing required for this kind of photo session, there are elements that represent routine, daily practices. Mercè Vilar, ${ }^{22}$ the teacher in the images, recounts

\footnotetext{
20 Pierre Bourdieu, La fotografía: un arte intermedio (México: Nueva Imagen, 1979).

21 Roland Barthes, La cámara lúcida. Nota sobre la fotografía (Barcelona: Paidós, 1990).

22 Mercè Vilar Monmany (born in 1954) was professor at the Faculty of Education Sciences of the Autonomous University of Barcelona (UAB) between 1979 and 2018. Holder of an Advanced Degree in Music Teaching from the Municipal Conservatory of Barcelona, Vilar completed her education by attending SMP-ISM courses and finally became a teacher at the same institution and a member of its technical staff. She specialized in the field of music teaching and worked as a music teacher in
} 
feeling totally identified and familiar with the strategies used during the photo session. Thus, the classroom dynamics that the images capture represent her daily teaching practices, which were based on the foundations of the Ireneu Segarra method. ${ }^{23}$

The session was carried out in a fourth-grade classroom at the UAB's Student Teaching School. Today the Bellaterra School, ${ }^{24}$ the school was founded in 1978. In addition to serving as a place for UAB student teachers to practice teaching, it also served as a center for experimenting with new pedagogies. At the time, only general teachers were employed, rather than those specialized in teaching a particular subject. They were largely teachers with positions at other public schools and were admitted to the Student Teaching School based on their particular merits. It was an experimental school with a special status that was recognized by other educational institutions. Work placements at the school were not permanent; rather, teachers worked there for specific periods of time to complete educational research and experiments. Teachers at the school were chosen by the center's management staff based on specific criteria, which included cooperative efforts between the university's teaching and research staff, and the introduction of new strategies and materials taking an active approach to education. ${ }^{25}$

Students were at the center of the school's teaching/learning process. They made decisions and gave opinions regarding aspects that concerned them, whether academic, organizational, or a combination of the two. There was a democratic approach to life at the school, exemplified by class meetings. Additionally, cultural roots and a feeling of belonging were fostered via local community work and the use of Catalan as the working language. The methodology took the interdisciplinary and transversality of contents into account, and included the teaching of the arts (dance, music, and visual arts). ${ }^{26}$

Regarding music teaching, the UAB decided to introduce weekly, one-hour sessions taught by various professors, the majority of whom were specialists from the Faculty of Education Sciences. These included Mercè Vilar, Pere Godall, Margarida Barbal, Núria Lluveras, and Pere Serra. While there was no official institutional collaboration between the UAB and the SMP-ISM, most of the professors from both institutions had a deep understanding of the Segarra method. Many of them were also teachers on SMP-ISM courses and collaborated on various editions of the method adapted to normal schools and conservatories. It is no coincidence that the majority

primary schools and music schools. Later, she focused on the training of music teachers at the introductory level and in continuing education programs at the university. She was the cofounder of the Music, Voice, and Education Research Group at the UAB.

23 Mercè Vilar, personal communication, October 25, 2019, 64 min.

24 A public school in the municipality of Cerdanyola del Vallès (Catalonia), located on the UAB's university campus in the Bellaterra neighborhood.

25 Mercè Vilar, personal communication.

26 Mercè Vilar, personal communication. 
of music professors at the UAB maintained a close connection to the SMP-ISM, since its main objective was to introduce and implement mandatory music teaching. ${ }^{27}$

The photo session under consideration was conducted by an unidentified professional photographer who was contracted by the school. ${ }^{28}$ The institution was especially interested in having photos taken of real situations and specific activities in music classrooms, to reflect and publicize the implementation of the Ireneu Segarra method in schools. According to Vilar's recollection, the photographer insisted on repeating specific exercises related to the Segarra methodology in order to photograph the various actions from different perspectives. This is in line with the SMP-ISM's interest in capturing specific images that would represent the method and its application. Vilar admits that the photo session was not conducted during a normal class, although she does state that she remembers feeling comfortable during the session, as it was a summary of her routine practices. $^{29}$

For our analysis of the 22 photographs, we discerned categories for the teaching and musical elements that appear. Many elements appear across various photographs; similarly, a single photograph can often include many of these elements. The photographs show the musical elements, tools, and strategies that are most representative of the application of the Ireneu Segarra method: intonation/phonomimic system (in five photos), collective singing (in five), rhythm/movement (in four), tabletop music staffmovable do (in four), and listening/dictation (in three). Materials published by the SMP-ISM for use in schools also appear in seven of the photographs. In addition to aspects related to music teaching, 18 images show elements representing educational innovations: grouping students, arrangement of furniture, architectural design, proximity of the teacher, individualized attention, etc. The set of images aims to reflect the innovative nature of the Segarra method for music teaching in schools.

As an overview here, we concentrate our analysis on five photographs that we deem to be representative of the entire collection. While focusing mostly on issues pertaining to music education, other general aspects related to innovative pedagogies are also present. We utilize the musical terminology employed by the Ireneu Segarra method, such as music reading and writing, collective or group singing, song, improvisation, composition, phonomimic system, relative solfège or movable do solfège, rhythm and melody flashcards, tabletop music staff, etc. We also make reference to more general aspects, such as the role and location of the students and teacher in the classroom, characteristics of the classroom, etc.

Fig. 3.1 shows Mercè Vilar directing the collective singing of a group of children. Based on her body language and her gaze (and as recognized by Vilar herself), the

27 Mercè Vilar, personal communication.

28 According to M. Vilar, the photos were taken by a well known photographer in the world of Catalan music, who had previously taken official photographs of the Palau de la Música, among other locations. Mercè Vilar, personal communication.

29 Mercè Vilar, personal communication. 
class is a small group. ${ }^{30}$ The consistent placing of students into groups of four or five facilitated this classroom practice, while fostering and incentivizing the listening work done by the rest of the students. Thus, this image is iconographic of two of the most important tools in the Segarra method: song and the practice of collective singing. Segarra recommended beginning students' musical education through song, particularly during their early years, in order to bring out the elements needed to study music in its entirety. By creating songs adapted to the prosody of the Catalan language, the method ensured that the language would endure and that students would feel a sense of cultural belonging, in line with the center's ideology. These two practices were closely tied to voice training - a key part of the Segarra method that can be found referenced in many of the photos in the collection. According to the method, voice is the most important tool for the practice and study of music in schools, and the voice of a child, in particular, is a delicate instrument with unlimited potential but which requires proper use. As Mercè Vilar recounts, the voice of the teacher serves as a point of reference, especially in the early stages of music education. ${ }^{31}$

Listening, both to the vocal repertoire performed in the classroom as well as the great works from the world of musical literature, is another of the key aspects of the Ireneu Segarra method. It played a part in the school's music sessions, complemented comprehensive training in music, and gave students their own tools for assessing the art.

We also note elements in the photo that are not specifically related to music, but which represent innovative educational activity at the center. Placing students in the classroom into groups of four or five responded to the school's effort to foster teamwork among children, under a framework of co-education and learning based on the intellectual, social, and gender heterogeneity of the group. Though the classroom is not exceedingly large nor particularly adapted to the practice of music, we can see in the image that it is well lit by exterior light. Vilar recounts that these large glass windows faced an interior patio that could be accessed exclusively by two adjacent classrooms. In this patio, students had at their disposal materials, educational games, and a school garden that the students themselves tended. ${ }^{32}$

Many of the strategies used in the Segarra method were based on cooperative work and group music practice, which fits well with the strategy of ensuring the close bond between teachers and students. In Fig. 3.2, the teacher is very close to students, both physically and in her facial expression towards them. In fact, Vilar has lowered her head so that she is on the same level as the group of students. She is giving them relevant explanations regarding the work that they are doing: an activity involving a tabletop music stave, five horizontal lines on which students can place counters

30 Mercè Vilar, personal communication.

31 Mercè Vilar, personal communication.

32 Mercè Vilar, personal communication. 


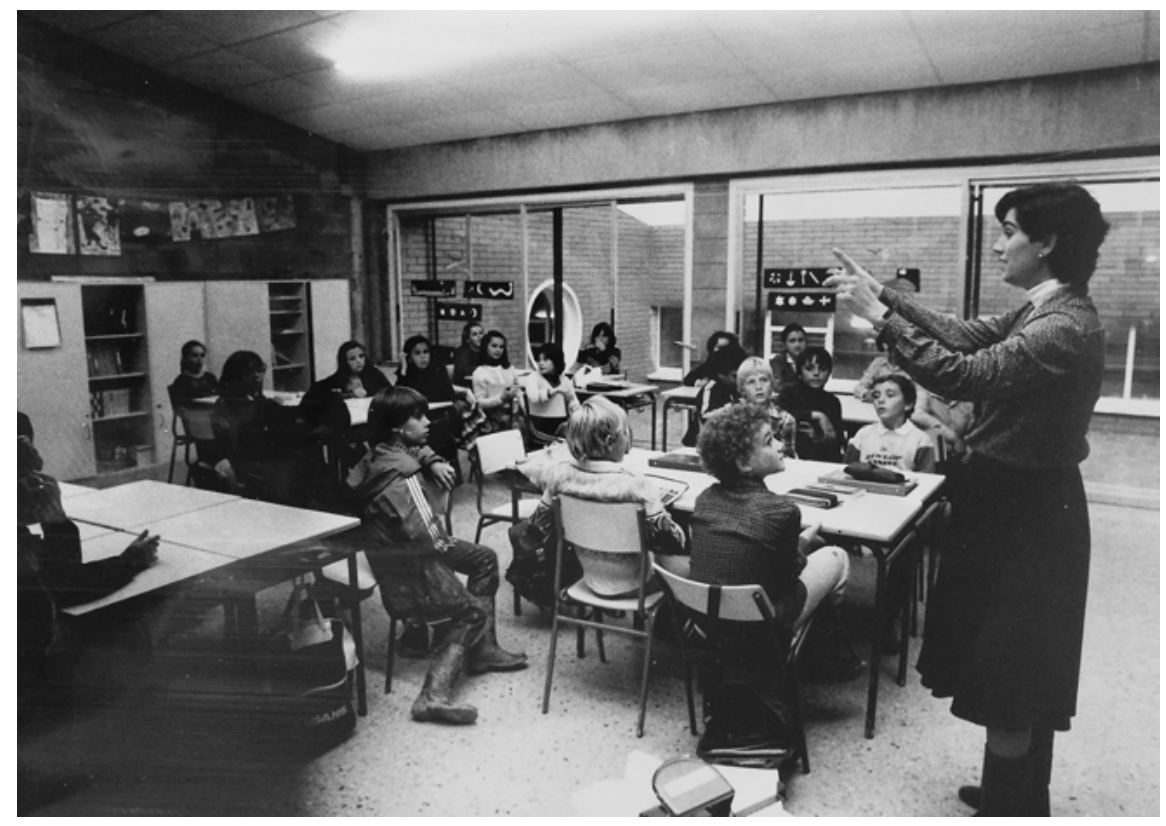

Fig. 3.1: Collective singing practice directed by teacher M. Vilar. Source: SMP-ISM. Photographs 1988-2003 (20th and 25th anniversaries). F-3, SMP-ISM Archives, Music Archives at the Abbey of Montserrat.

representing notes. This tool aided a type of music reading and writing education known as "solfège", wherein musical notes are paired with a syllable (do-re-mi is the most common English example). The counters, three along a stave, form a chord. By changing the position of the counters, known as relative solfège or a movable do, students are taught how to read music in different keys. Vilar commented that when the photo was taken, the students were creating small compositions using the movable notes; later she would perform their compositions, providing them with new instructions and suggestions for improvement. ${ }^{33}$

In the Ireneu Segarra method, music reading and writing are paramount to creating a basic knowledge of sheet music, the first step towards interpreting the signs in practice. In this way, connections are established between everything that has been learned, and simple, unspecific interpretations are avoided. The tabletop music stave allows students to create and experiment with different sounds, while learning to locate them on a graphic code. This creative process stimulates inventive skills and helps students discover the possibilities of musical notation. It is, in our opinion, one

33 Mercè Vilar, personal communication. 
of the best mechanisms for interiorizing musical language and discovering its more artistic dimensions in a larger space.

However, learning musical notation, whether through syllables, notes or intervals, is only a step towards a larger goal: the relationships between sounds, rhythms, and melodies intrinsic to a musical context or situation. In most cases, this context is the song itself, assimilated and experienced as an expressive element, and from which concepts can be extracted to form musical language. Each new learning experience is reinforced by previous ones through a process of aural comparison and recognition. Thus, in our case, there is a correlation between Photographs 3.1 and 3.2. First we sing, then we theorize.

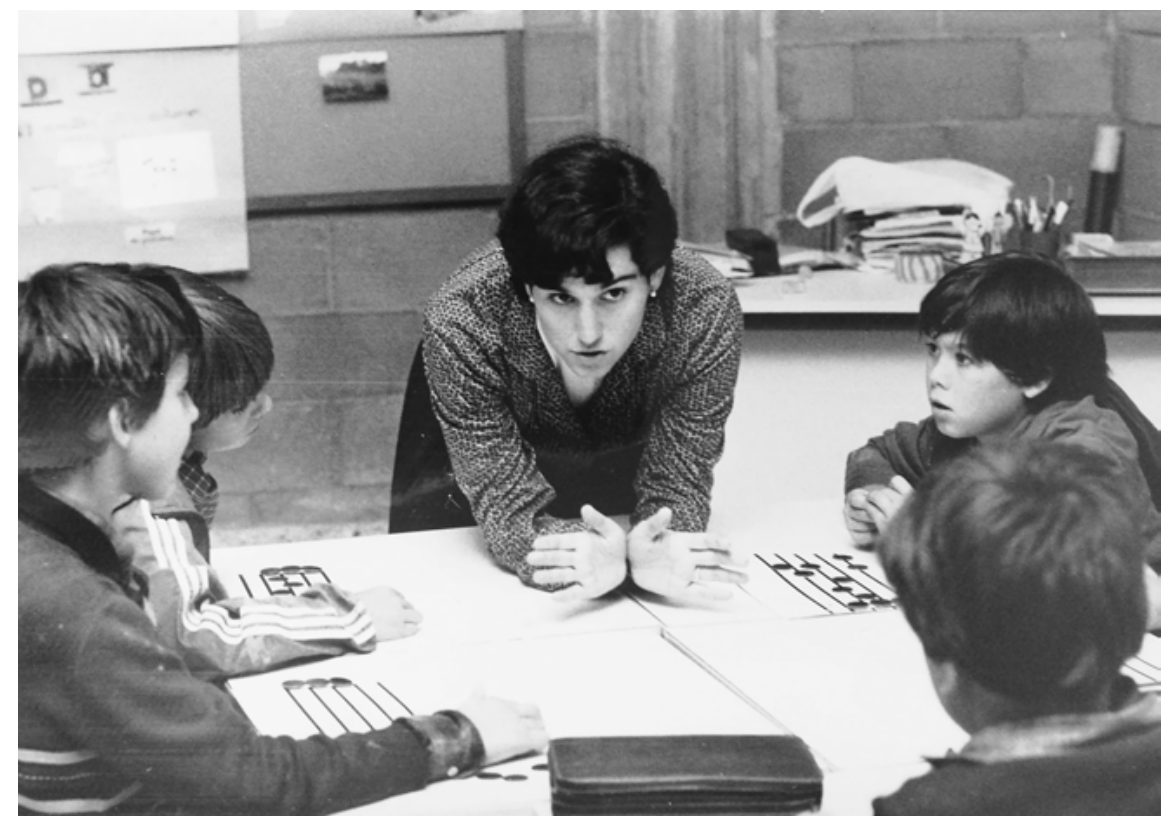

Fig. 3.2: Teacher and students with a tabletop music stave. Source: SMP-ISM. Photographs 1988-2003 (20th and 25th anniversaries). F-3, SMP-ISM Archives, Music Archives at the Abbey of Montserrat, Opuscle 33.

In Fig. 3.3, a student is at the board writing a formula for rhythm - possibly a dictation activity. The teacher may have previously performed a rhythm that the students were to memorize and then transpose into written format. In the Segarra method, rhythm is taught in terms of movement: individual and group coordination as well as freedom of movement. It focuses on beat, ostinato, polyrhythms, the proportions and relations between phrases, etc. The lack of activities related to movement and dance in the collection of photographs is noteworthy as, according 
to M. Vilar, such activities were indeed carried out during the session. ${ }^{34}$ It is surprising that they were not photographed, or if they were, that they have been lost: they were activities that were representative of the Ireneu Segarra method and are widely documented iconographs in other contexts in SMP-ISM photos.

Interpreting notated music, whether rhythmic or melodic, involves the mind's ear. This aspect is greatly important to the Segarra method and often focused on in SMPISM courses. It places emphasis on the ability to mentally represent audio perceptions, even internal ones. Everyone possess an internal ear - our mind's ear - and its abilities can be improved with specific training that initially focuses on the relationship between two simple sounds, and which gradually introduces higher degrees of complex counterpoint and harmonic relationships. Working with dictated melodies and rhythms is the first step in the process of developing the mind's ear.

In Fig. 3.3 we also see the photographer's (and the SMP-ISM's) intent to show professors and students using materials published by the institution. As previously mentioned, the school published books for students and teachers, flashcards, listening activities, rhythm and melody posters, etc. In the image, we can see the teacher holding one of these rhythm flashcards, possibly one used for dictation. One of the photographs in the collection shows a sample of these publications and materials, which were widely welcomed by music teachers across Catalonia and the Balearic Islands.

Fig. 3.4 brings together all the aspects of the Segarra method which we have already analysed. Here, the students have been given tabletop musical staves and counters, and Vilar has written a stave of the blackboard. She is asking for the students to be silent, a gesture made by placing an extended index finger at the front of the mouth, while she performs melodic dictation. Meanwhile, the teacher's left hand is performing the dictation using phonomimics, aimed at students either placing the notes that they perceive on the tabletop music stave or singing them. The phonomimic system - or the association of gestures with sounds - is a tool commonly used in Segarra's methodology, and was influenced by Kodály. Essentially, it teaches students about tune, allowing them to perceive each note at its proper pitch: gestural memory becomes associated with auditory memory. Phonomimics can be applied to various aspects of music, including pitch, training the auditory discriminations and memory, musical intervals, polyphony, and preparing for tonal modulation. Melody and pitch represent important elements in the initial stages of music learning with regard to the auditory understanding of rising and falling sounds. They are also important for more advanced concepts, such as the relationship between phrases in the context of tone and mode, the sense of cadences, and interval intonation for melodies and harmonies.

34 Mercè Vilar, personal communication. 


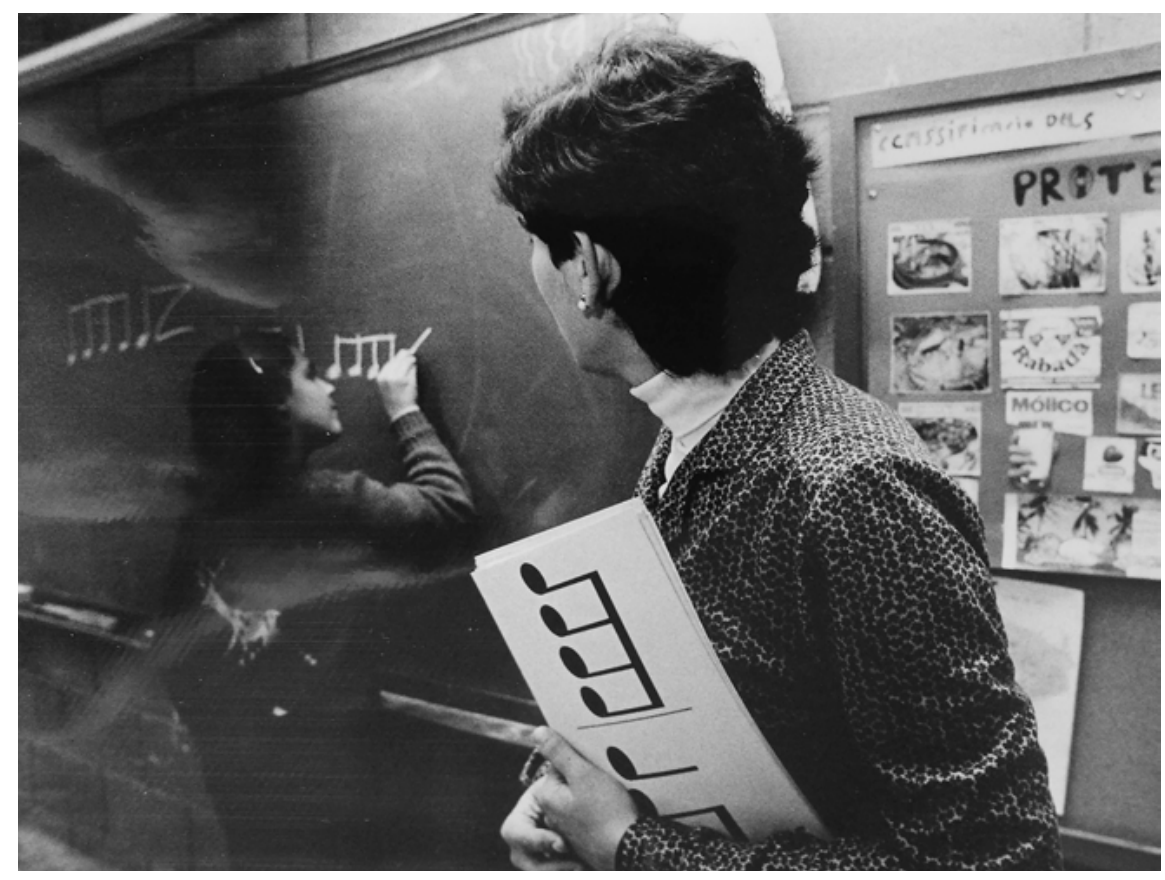

Fig. 3.3: Student writing a rhythm formula on the blackboard. Source: SMP-ISM. Photographs 1988-2003 (20th and 25th anniversaries). F-3, SMP-ISM Archives, Music Archives at the Abbey of Montserrat.

Finally, Fig. 3.5 depicts a symbolic offering from the teacher to the students, allowing them to take center stage in the teaching/learning process - a process in which music becomes a source of enjoyment, and a medium through which students can communicate to each other and express themselves freely. According to the Segarra method, this role exchange must be adapted to each student's age, ability, and needs. Moreover, students are taught to perform music, to move with a beat and to feel a cadence (the fall at the end of a musical phrase), before they are taught the mechanics lying behind music, analyzing rhythms or meter. In this sensory-based educational paradigm, it is key to feel and move to the cadence of the beat before analyzing rhythms or meters. Learners must also intonate and sing properly before knowing the names of the notes or analyzing intervals, and before being expected to properly relate music/word/movement concepts. These practices increase musical creativity and improvisation, which are essential for assimilation and understanding.

All the musical aspects included in the Segarra method, and reiterated in the analyzed collection of photographs, aim to turn music into a vibrant, active element in schools in Catalonia. In the SMP-ISM's tenth anniversary booklet Maria Antònia Canals i Tolosa, a teacher specializing in the Montessori system and one of the founders 


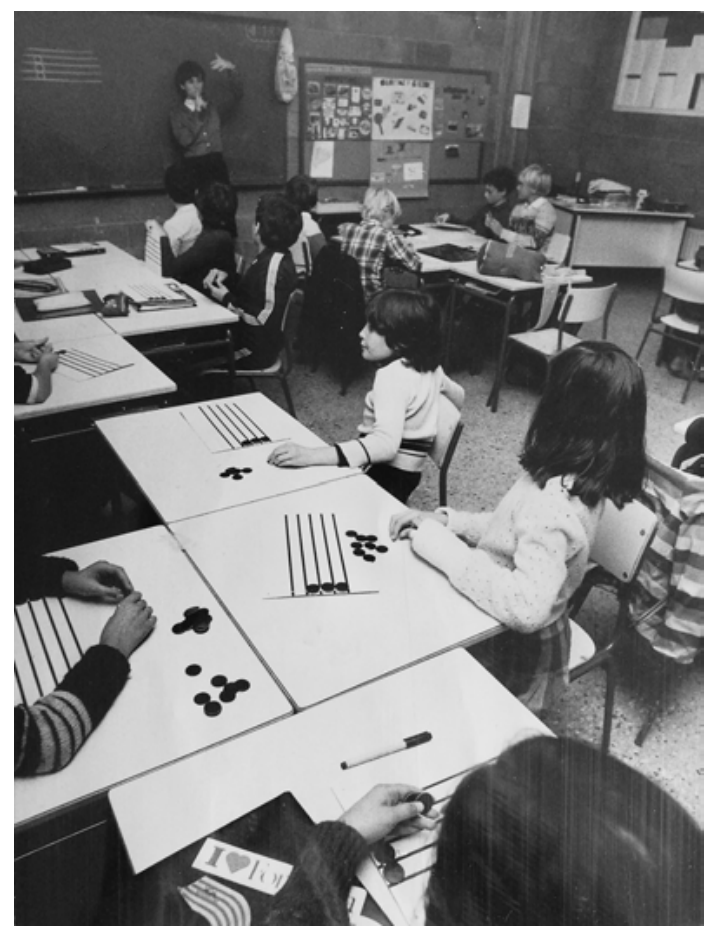

Fig. 3.4: Melody dictation. Source: SMP-ISM. Photographs 1988-2003 (20th and 25th anniversaries). F-3, SMP-ISM Archives, Music Archives at the Abbey of Montserrat. Published in Escola, Opuscle 38.

of the Rosa Sensat Teachers' Association, ${ }^{35}$ wrote that music should be the most unrelenting work for teachers in schools. She saw music fulfilling the most fundamental goals of education, including the development of logical and creative thought, and the ability to express oneself imaginatively. ${ }^{36}$

In the context of the teaching redevelopment that took place in Catalonia during the 1970s and 1980s - and schools not previously teaching music - it is remarkable that leaders in the field during this transitional period had the vision to deem it necessary to finally introduce music into schools. Through their teaching initiatives,

35 The Rosa Sensat Teachers' Association (La Asociación de Maestros Rosa Sensat) is an association of Catalan educators that aims to improve the quality of teaching and education in general. It was founded in 1965 as the Rosa Sensat Teachers' School (Escuela de Maestros Rosa Sensat), and took its current name in 1980. It offers continuing education courses for teachers (notably, summer schools), accommodates various work groups, organizes workshops and debates, and oversees the creation of a number of renowned publications, such as Perspectiva Escolar, Infància, Infància a Europa, and Infancia latinoamericana (URL: https://www.rosasensat.org/).

36 Escola, Opuscle commemoratiu, 35. 


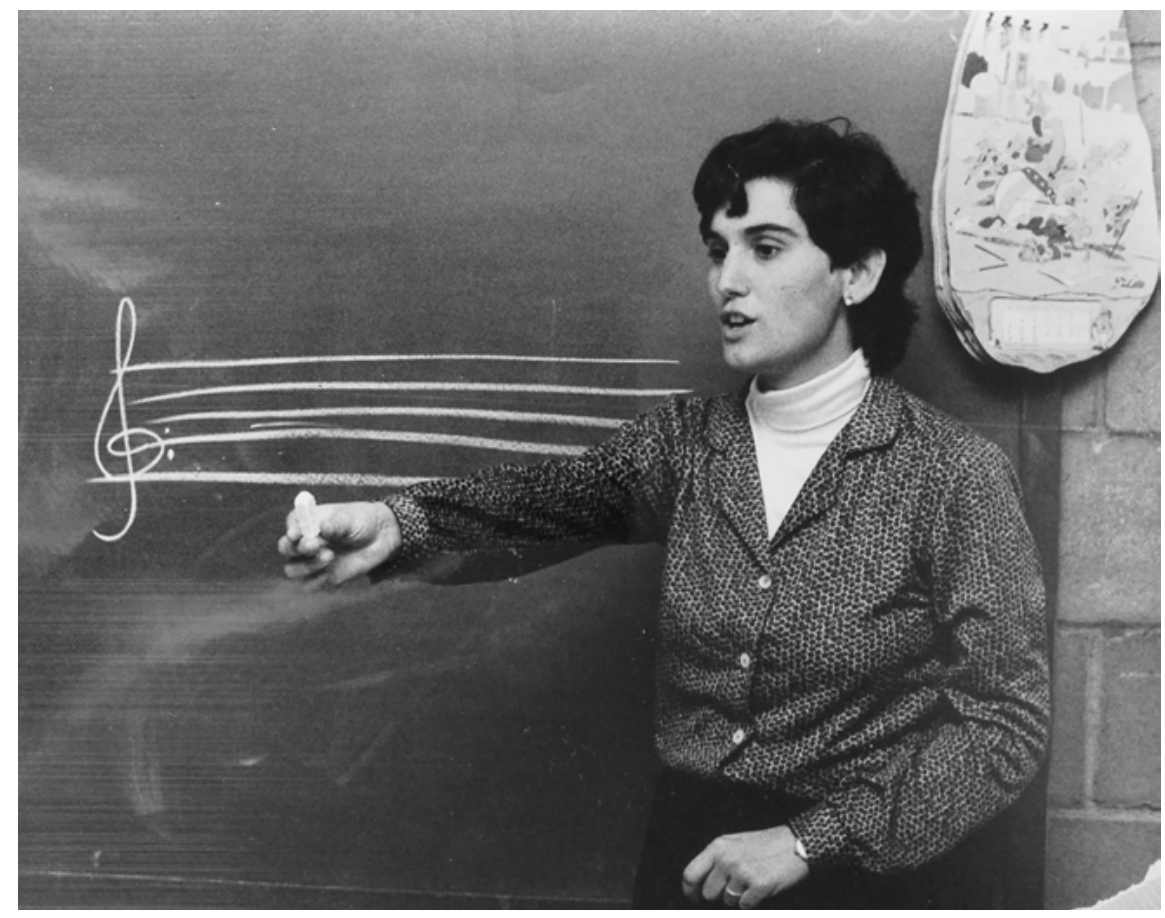

Fig. 3.5: M. Vilar offering chalk to students. Source: SMP-ISM. Photographs 1988-2003 (20th and 25th anniversaries). F-3, SMP-ISM Archives, Music Archives at the Abbey of Montserrat.

the SMP-ISM aimed to establish a new educational framework that would offer teachers training in the arts, aesthetics, and music that was equal to their training in other subject matters. And this learning was to be based on experiences and creativity, both of which are important in personality development. To accomplish this, teachers had to be trained at the highest possible level in order to ensure success in this educational process.

\section{Conclusions}

The relevance of the photographs analyzed here lies in the fact that they were created for public display. They were designed to serve as an iconographic compendium of the main educational innovations of the Ireneu Segarra method applied to primary education. Commissioned by the SMP-ISM, the photographs were taken by a professional photographer and to be used for propaganda and advertisement purposes for the method in a book commemorating the first ten years of the institution's foundation. Thus, the photos present an idealised teaching environment, deliberately 
focusing on the innovative educational practices related to what the institution represented and wished to project.

Accordingly, the school had a special interest in photographing real life situations where specific activities from the music classroom took place, in order to reflect and publicize the implementation of the Ireneu Segarra method in schools. Photographs were taken of aspects and elements that iconographically represent the method and its application in schools. In this way, we are able to confirm the presence of the various teaching and musical elements that were repeatedly captured in the photographs.

As a whole, the collection reflects elements that were related to, or were themselves, innovative educational practices: dividing classes into small groups, arranging furniture to facilitate cooperative work; the proximity of teachers and students, alternating between the teacher doing work and the group/class doing work. etc.

In terms of the Ireneu Segarra method and its application in schools, the central elements in the photos include: intonation and phonomimics, collective singing, rhythm and movement, the tabletop music stave and the movable do, and listening and dictation. Many photos also show materials published by the SMP-ISM to be used in schools, as well as their use by students and teachers.

Nevertheless, the lack of photographs showing movement and dance is surprising, since they are activities deemed as iconographic and representative of the method, and have been widely documented as such in other photo collections from the SMP-ISM, e.g., in photos of teacher training courses.

Ultimately, though, the set of photographs does provide an iconographic reflection of what the SMP-ISM wished to highlight and show to the public regarding the Segarra method's main innovative pedagogies and materials for music teaching in schools.

\section{Bibliography}

Barthes, Roland. La cámara lúcida. Nota sobre la fotografía. Barcelona: Paidós (Paidós Comunicación, 43), 1990.

Bourdieu, Pierre. La fotografía: un arte intermedio. México: Nueva Imagen, 1979.

Casals, Joan. "El método Ireneu Segarra." Música y Educación. Revista trimestral de pedagogía musical 16 (1993): 51-74.

Comas, Francisca, Xavier Motilla, and Bernat Sureda. "Escuela y fotografía, entre el testimonio y la construcción del discurso narrativo." In Patrimonio y Etnografía de la escuela en España y Portugal durante el siglo XX, edited by Pedro L. Moreno and Ana Sebastián, 405-417. Murcia: SEPHE, CEME, Universidad de Murcia, 2012.

Comas, Francisca, Bernat Sureda and Xavier Motilla. "Pedagogical innovation and music education in Spain: Introducing the Dalcroze method in Catalonia." Paedagogica Historica vol. 50-3 (2014): 320-337.

Comellas, Jaume. "Ireneu Segarra: el sacerdoci de la música i la pedagogia musical." Revista Musical Catalana 47 (1988): 37-43. 
Cortina, Joan. “L’Escola de Pedagogia Musical-Mètode Ireneu Segarra." In Ireneu Segarra. Mig segle de mestratge musical, AA. VV., 57-59. Barcelona: Abadia de Montserrat, 1998.

Escola de Pedagogia Musical-Mètode Ireneu Segarra. Opuscle commemoratiu dels 10 anys de l'Escola de Pedagogia Musical. Barcelona: Patronat Pro-Música, Fundació Güell, 1984.

Garrigosa, Joaquim. “L’Escola de Pedagogia Musical-Mètode Ireneu Segarra.” Perspectiva escolar 155 (1991): 16-19.

Gelabert, Llorenç. "Aproximación histórica y metodológica a los cursos de pedagogía musical de la Universitat de les Illes Balears (1977-1990)." Historia de la Educación. Revista Interuniversitaria 34 (2015): 337-356.

Gelabert, Llorenç, and Xavier Motilla. "Aproximación al movimiento de renovación de la práctica educativa a través de la Escuela de Pedagogía Musical-Método Ireneu Segarra." In La Práctica Educativa. Historia, Memoria y Patrimonio, edited by Sara González, Juri Meda, Xavier Motilla and Luigiaurelio Pomante, 573-582. Salamanca: FahrenHouse, 2018.

Gelabert, Llorenç, and Xavier Motilla. "Renovación de la enseñanza de la música e identidad catalana en los inicios de la Escuela de Pedagogía Musical-Método Ireneu Segarra." In 20 Coloquio Historia de la Educación. Identidades, Internacionalismo, Pacifismo y Educación (s. 19 y 20), edited by Xosé M. Cid and Victoria Carrera, 261-266. Ourense: SEDHE, Deputación de Ourense, 2019.

Gelabert, Llorenç and Xavier Motilla. "School Textbooks, Didactic Material and a New Approach in Music Teaching in Catalonia with the Opening of the School of Musical Pedagogy-Ireneu Segarra Method." History of Education \& Children's Literature, 152 (2020): 183-198.

Miranda, Joaquim. "El mètode Ireneu Segarra i l'escola de pedagogía musical." In Primer Congrés de Música de Catalunya, AA. VV., 299-303. Barcelona: Consell Català de la Música, 1994.

Panofsky, Erwin. Studies in Iconology: Humanistic Themes in the Art of the Renaissance (1939). Boulder, CO, USA: Taylor and Francis, 1972

Riera, Santi. "L’aportació pedagògica." In Ireneu Segarra. Mig segle de mestratge musical, AA. VV., 37-55. Barcelona: Publicacions de l'Abadia de Montserrat, 1998.

Segarra, Ireneu, Juguem Cantant. 50 cançons per a la iniciació musical. Barcelona: Publicacions de l'Abadia de Montserrat, 1973.

Segarra, Ireneu. Iniciació a la Música. Llibre del Professor. I Grau. Barcelona: Publicacions de l'Abadia de Montserrat, 1974.

Segarra, Ireneu. 40 fitxes de El meu llibre de música. Primer Grau. Barcelona: Publicacions de l'Abadia de Montserrat, 1976.

Segarra, Ireneu. Iniciació a la Música. Llibre del Professor. 2 Grau. Barcelona: Publicacions de l'Abadia de Montserrat, 1977.

Segarra, Ireneu. Iniciació a la Música. Llibre del Professor. 3 Grau. Barcelona: Publicacions de l’Abadia de Montserrat, 1978.

Segarra, Ireneu. Iniciació a la Música. Llibre del Professor. 4 Grau. Barcelona: Publicacions de l'Abadia de Montserrat, 1979.

Segarra, Ireneu. El meu llibre de música. Segon Grau. Barcelona: Publicacions de l'Abadia de Montserrat, 1981.

Segarra, Ireneu. 30 fitxes de El meu llibre de música. Segon Grau. Barcelona: Publicacions de l'Abadia de Montserrat, 1981.

Segarra, Ireneu. El meu llibre de música. Primer Grau. Barcelona: Publicacions de l'Abadia de Montserrat, 1983.

Segarra, Ireneu. El meu llibre de música. Tercer Grau. Barcelona: Publicacions de l'Abadia de Montserrat, 1983.

Segarra, Ireneu. Iniciació a la Música. Llibre del Professor. V Grau. Barcelona: Publicacions de l’Abadia de Montserrat, 1983. 
Segarra, Ireneu. 27 fitxes de El meu llibre de música. Tercer Grau. Barcelona: Publicacions de l'Abadia de Montserrat, 1984.

Segarra, Ireneu. El meu llibre de música. Quart Grau. Barcelona: Publicacions de l'Abadia de Montserrat, 1984.

Segarra, Ireneu. 30 fitxes de El meu llibre de música. Quart Grau. Barcelona: Publicacions de l'Abadia de Montserrat, 1985.

Segarra, Ireneu. El meu llibre de música. Cinquè Grau. Barcelona: Publicacions de l'Abadia de Montserrat, 1986.

Segarra, Ireneu. Iniciació a la Música. Llibre del Professor. 6 Grau. Barcelona: Publicacions de l'Abadia de Montserrat, 1989.

Segarra, Ireneu. Iniciació a la Música. Llibre del Professor. 7 Grau. Barcelona: Publicacions de l'Abadia de Montserrat, 1990.

Segarra, Ireneu. El meu llibre de música. Sisè Grau. Barcelona: Publicacions de l’Abadia de Montserrat, 1989.

Segarra, Ireneu. El meu llibre de música. Setè Grau. Barcelona: Publicacions de l’Abadia de Montserrat, 1993.

Segarra, Ireneu. El meu llibre de música. Vuitè Grau. Barcelona: Publicacions de l'Abadia de Montserrat, 1993.

Segarra, Ireneu. Iniciació a la Música. Llibre del Professor. 8 Grau. Barcelona: Publicacions de l'Abadia de Montserrat, 1994. 
